\title{
IMPLEMENTASI PENDIDIKAN KARAKTER MELALUI BIDANG STUDI PENDIDIKAN KEWARGANEGARAAN
}

\author{
Muhammad Yunan Suhardiyansyah, Budiono, Rohmad Widodo \\ FKIP Universitas Muhammadiyah Malang, Indonesia \\ Email : Yunan-Truve@yahoo.com
}

\begin{abstract}
Research conducted at SMAN 9 Malang about, (1) Implementation of Character Education by Study of Citizenship, (2) Describe the constraints faced, (3) Describe solution made in the implementation of Character Education by Study Of Citizenship. This research uses the nearing of qualitative research. Where researchers directly to collecting information related to the title of the study. The collection of data obtained from observation, interview, and documentation. As for the target of information are principal, waka kurikulum, waka student, teacher Citizenship Education, and the student of SMAN 9 Malang. Indicate that the results of research in Citizenship Education in SMAN 9 Malang loading about Character Education and devolep values's character that exist in the state ideology that is Pancasila, strategic Citizenship Education teachers of SMAN 9 Malang are with model. Habituation or reinforcement. Evaluation is conducted by the Citizenship Education teacher at SMAN 9 are cognitive, affective and psychomotor student. Values in Citizenship Education also developed in school extracurriculier activities such as extracurricular activities paskibra in SMAN 9 Malang which also inserts character education such as discipline, responbility, independence, and nationalist. It's just that in practice there are still constraints such as there are still a few of student who make mischief in school, many teacher and students who come school late. From the times or the impact that the school conducted globalisasi. The solution of the schools that model, an awareness of the self, the role of parents.
\end{abstract}

Keyword: Implementation; Character Education; Study of Citizenship

\section{PENDAHULUAN}

Pemerintah menjadikan pembangunan karakter sebagai salah satu program prioritas pembangunan nasional. Semangat itu secara implisit ditegaskan dalam Rencana Pembangunan Jangka Panjang Nasional (RPJPN) tahun 2005-2025, (Sisdiknas) di mana pendidikan karakter ditempatkan sebagai landasan untuk mewujudkan visi pembangunan nasional, yaitu "Mewujudkan masyarakat berakhlak mulia, bermoral, beretika, berbudaya dan beradab berdasarkan falsafah Pancasila."

Gambaran situasi masyarakat bahkan situasi dunia pendidikan di Indonesia menjadi motivasi pokok pengarusutan (mainstreaming) implementasi pendidikan karakter di Indonesia. Pendidikan karakter di Indonesia di rasakan amat perlu pengembangannya bila mengingat makin meningkatnya tawuran antar pelajar serta bentuk-bentuk kenakalan remaja lainnya terutama di kota-kota besar, pemerasan dan kekerasan (bullying), penggunaan narkoba, minum-minuman keras dan lain-lain. Informasi dari badan narkotika nasional menyatakan ada 3.6 juta pecandu narkoba di Indonesia Tempo interaktif (Samani dan Hariyanto, 2012)

Fenomena lain yang sangat mencoreng citra pelajar dan lembaga pendidikan juga adanya pergaulan bebas (free sex) yang dilakukan oleh para pelajar dan mahasiswa sebagaimana dilansir sexual behavior survey (dalam Gunawan 2012 : 1) yang telah melakukan surve di 5 kota besar di Indonesia, yaitu Jabodetabek, Bandung, Yogyakarta, Surabaya dan Bali pada bulan Mei 2011 dari 663 responden yang diwawancarai secara langsung mengakui bahwa 39\% responden remaja usia 15-19 tahun pernah berhubungan 
seksual, sisanya $61 \%$ berusia $20-25$ tahun. Lebih memprihatinkan berdasarkan profesi, peringkat tertinggi yang pernah melakukan free sex ditempati oleh para mahasiswa $31 \%$, karyawan kantor $18 \%$, sisanya ada pengusaha, pedagang, buruh dan sebagainya. Termasuk 6\% siswa SMP atau SMA Semua prilaku negatif masyarakat Indonesia baik yang terjadi di kalangan pelajar dan mahasiswa maupun kalangan yang lainnya, jelas menunjukan kerapuhan karakter yang cukup parah yang salah satunya disebabkan oleh tidak optimalnya pengembangan pendidikan karakter di lembaga pendidikan.

Gunawan (2012: 23) pendidikan karakter untuk membentuk kepribadian seseorang melalui pendidikan budi pakerti, yang hasilnya terlihat dalam tindakan nyata seseorang yaitu tingkah laku yang baik, jujur bertanggung jawab, menghormati hak orang lain, kerja keras dan sebagaianya. Mulyasa, (2012: 8) mengemukakan bahwa pendidikan karakter sangat terkait dengan manajemen atau pengelolaan institusinya.

Pengelolaan institusi yang di maksud adalah bagaimana pendidikan karakter di rencanakan dilaksanakan, dan dikendalikan dalam kegiatan-kegiatan pendidikan di dalam institusi tersebut secara memadai. Namun tampaknya upaya pendidikan yang dilakukan oleh lembaga pendidikan dan institusi pembina lain belum sepenuhnya mengarahkan dan mencurahkan perhatian secara komprehensif pada upaya pencapaian tujuan pendidikan nasional yaitu "Pendidikan nasional berfungsi mengembangkan dan membentuk watak serta peradaban bangsa yang bermartabat dalam rangka mencerdaskan kehidupan bangsa. Bertujuan untuk berkembangnya potensi peserta didik agar menjadi manusia yang beriman dan bertakwa kepada Tuhan Yang Maha Esa, berakhlak mulia, sehat, berilmu, cakap, kreatif, mandiri, dan menjadi warga negara yang demokratis serta bertanggung jawab" (Undang-undang
Republik Indonesia Nomor 20 Tahun 2003 tentang Sistem Pendidikan Nasional UUSPN).

Pendidikan Kewarganegaraan (PKn) merupakan salah satu konsep pendidikan yang berfungsi untuk membentuk siswa sebagai warga negara yang mempunyai karakter. Keterkaitan PKn terhadap pengembangan karakter di kemukakan oleh Samsuri (2011: 20) yang menyatakan PKn memiliki dimensi-dimensi yang tidak bisa di lepaskan dari aspek pembentukan karakter dan moralitas publik. PKn bertujuan untuk membangun karakter (character bulding) bangsa Indonesia yang antara lain:

a) Membentuk kecakapan partisipatif warga negara yang bermutu dan bertanggung jawab dalam kehidupan berbangsa dan bernegara

b) Menjadikan warga negara yang cerdas, aktif, dan demokrastis,namun tetap memiliki komitmen menjaga persatuan dan integritas bangsa, dan,

c) Mengembangkan kultur demokrasi yang berkeadaban, yaitu kebebasan, persamaan, toleransi dan bertanggung jawab.

Maraknya isu dari berbagai pihak yang menyoroti penyelenggaraan sistem pendidikan nasional yang belum dapat menghasilkan lulusan yang berkualitas, termasuk wawasan sikap dan prilaku. Tudingan akan rendahnya kualitas lulusan ini selalu saja mengarah pada kegagalan pembelajaranPendidikanKewarganegaraan. Sebagai bukti dengan menunjukan sikap dan prilaku tidak terpuji yang sedang mengejala, Realita dalam observasi yang dilakukan di SMAN 9 Kota Malang yang menunjukkan beberapa kebiasaan murid yang menjadikan sebuah budaya seperti plagiarisme dalam pengerjaan tugas-tugas sekolah, kebiasaan merokok di sekolah atau membawa rokok di sekolah, bolos sekolah, gaya berpakaian, penggunaan teknologi atau handphone secera belebihan di dalam 
kelas ketika guru sedang mengajar.

Terdapat kesenjangan dengan motto smanawa(smitaacityanalarwagadi)SMAN 9 Kota Malang yang mengejawantahkan ke dalam perwujudan pendidikan karakter yang cerdas dan dilandasi dengan sifat religius. SMAN 9 Kota Malang berusaha selalu mengedepankan peran aktif guru dan siswa dengan ditunjang seluruh komponen yang ada dalam meraih citacita dan prestasi yang diinginkan. Semua diwajibkan memiliki program kerja sebagai salah satu instrumen dalam meraih target dan tujuan pendidikan. SMAN 9 Kota Malang bertekad untuk berperan serta aktif dalam membangun dunia pendidikan khususnya di Kota Malang. Telah banyak prestasi baik di bidang akademis seperti Olimpiade Sains, Event antar siswa dan sekolah maupun prestasi non akademik seperti bidang olahraga, seni, budaya dan sebagainya. Berdasarkan latar belakang tersebut peneliti tertarik untuk mengadakan penelitian yang berjudul " Implementasi pendidikan karakter melalui bidang studi Pendidikan Kewarganegaraan di SMAN 9 Kota Malang”.

\section{METODE}

Penelitian ini menggunakan pendekatan kualitatif karena permasalahan yang di bahas dalam penelitian ini tidak berkenaan dengan angka-angka tetapi mendeskripsikan, menguraikan, dan menggambarkan tentang Implementasi Pendidikan Karakter Melalui Bidang Studi Pendidikan Kewarganegaraan Di SMAN 9 Kota Malang. Ide dari penelitian ini yaitu supaya kita dapat mengadakan pengamatan tentang sesuatu fenomena atau memperoleh hasil. Penelitian kualitatif adalah prosedur penelitian yang menghasilkan deskriptif berupa kata-kata atau tulisan dari orang atau perilaku yang di amati Bogdan dan Tylor (dalam Zuriah 2009: 92).

Sedangkan menurut Moleong (2011:

5) mengemukakan bahwa penelitian kualitatif adalah yang menggunakan pendekatan naturalistik untuk mencari dan menemukan pengertian atau pemahaman tentang fenomena dalam suatu latar yang berkonteks khusus.

\section{Gambaran SMAN 9 Kota Malang}

Dengan motto smanawa (smita acitya nalar wagadi) SMAN 9 Kota Malang mengejawantahkannya ke dalam perwujudan pendidikan karakter yang cerdas dan dilandasi dengan sifat religius. SMAN 9 Kota Malang berusaha selalu mengedepankan peran aktif guru dan siswa dengan ditunjang seluruh komponen yang ada dalam meraih cita-cita dan prestasi yang diinginkan. Semua diwajibkan memiliki program kerja sebagai salah satu instrumen dalam meraih target dan tujuan pendidikan. SMAN 9 Kota Malang berdiri pada tanggal 14 Agustus 1993. SMAN 9 Kota Malang mendukung program pemerintah pusat dalam mewujudkan perbaikan mutu pendidikan yang ada di Indonesia.

SMAN 9 Kota Malang beralamatkan di jalan Puncak Borubudor 1 Malang, Sekolah ini telah menghasilkan lulusan bermutu, berwawasan global dan berakhlak mulia. Guru-guru di SMAN 9 Kota Malang ini merupakan lulusan S1 dan S2 dari berbagai perguruan tinggi, bahkan beberapa guru S1 saat ini sedang menempuh pendidikan magister dan ada yang telah mendapatkan gelar Magister. SMA Negeri 9 Malang bertekad untuk berperan serta aktif dalam membangun dunia pendidikan khususnya di Kota Malang. Telah banyak prestasi baik di bidang akademis seperti Olimpiade Sains, Event antar siswa dan sekolah maupun prestasi non akademik seperti bidang olahraga, seni, budaya dan lain-lain.

\section{HASIL DAN PEMBAHASAN}

Berdasarkan penelitian yang dilakukan oleh peneliti dengan cara observasi dan wawancara kepada informan 
berkenaan dengan judul yang diteliti yakni Implementasi Pendidikan Karaketer Melalui Bidang Studi PKn. Pertama peneliti disini ingin mengetahui implementasi pendidikan karakter melalui pendidikan kewarganegaraan di SMAN 9 Kota Malang, kedua peneliti ingin mendeskripsikan kendala-kendala yang dihadapi dalam implementasi Pendidikan Karakter melalui Pendidikan Kewarganegaraan di SMAN 9 Kota Malang, dan yang ketiga peneliti ingin mendeskripsikan solusi yang dilakukan untuk mengatasi kendala-kendala dalam Implementasi Pendidikan Karakter melalui bidang studi Pendidikan Kewarganegaraan.

Berkaitan dengan penjelasan diatas maka peneliti akan uraikan hasil wawancara dengan para informan di SMAN 9 Malang yaitu Guru Pendidikan Kewarganegaraan, Kepala Sekolah, Waka Kesiswaan, Waka Kurikulum dan Siswa. Wawancara ini dilakukan dengan mnggunakan pedoman wawancara yang telah dibuat sebelumnya. Ini dikarenakan agar mempermudah proses wawancara dengan informan agar peneliti tidak mengalami kesulitan dalam melakukan wawancara dengan informan dalam mengumpulkan sumber informasi yang terkait dalam penelitian ini.

\section{Implementasi Pendidikan Karakter Melalui Bidang Studi Pendidikan Kewarganegaraan}

Pendidikan karakter itu adalah tugas semua komponen lembaga Pendidikan yaitu guru, keluarga dan sekolah khususnya Bidang studi PKn yang mencantumkan pendidikan karakter pada semua materi pelajarannya. Mengimplementasikan nilainilai karakter yang terkandung dalam Pendidikan Kewarganegaraan harus mampu diaplikasikan oleh peserta didik dalam kehidupannya seharihari, hal ini mendorong guru PKn di SMAN 9 Kota Malang untuk mampu mengembangkan nilai-nilai karakter tersebut yang didasari oleh Pancasila dan kehidupan sosial peserta didik sehingga akan terwujud tujuan dari pendidikan nasional yang didasari oleh Pancasila.

Fokus penelitian ini adalah bagaimana implementasi Pendidikan Karakter yang ada dalam Pendidikan Kewarganegaraan karena PKn merupakan salah satu mata pelajaran yang sangat penting yang mempunyai program utamanya yaitu untuk membentuk dan mengenalkan nilainilai karakter yang baik dalam diri peserta didik, dalam kaitannya dengan penjelasan diatas maka kedudukan mata pelajaran Pendidikan Kewarganegaraan sangatlah penting dalam lembaga pendidikan formal.

Kesimpulannya bahwa seluruh lembaga Pendidikan wajib untuk melaksanakan Pendidikan Karakter tidak hanya dilaksanakan oleh SMAN 9 Kota Malang. Karena tujuan dari Pendidikan Karakter sendiri yaitu untuk membentuk kepribadian seseorang menjadi lebih baik sesuai dengan norma-norma yang ada dalam kehidupan dan aturan-aturan yang ada, sesuai dengan pendapat dari Lickona (dalam Gunawan 2012:23) yang menyatakan bahwa pendidikan untuk membentuk kepribadian seseorang melalui pendidikan budi pakerti, yang hasilnya terlihat dalam tindakan nyata seseorang, yaitu tingkah laku yang baik, jujur, bertanggung jawab, menghormati hak orang lain, kerja keras, dan sebagainya. Dari sini sudah sangat jelas bahwa peran Pendidikan Kewarganegaraan di SMAN 9 Kota Malang yaitu untuk mendorong peserta didik dalam berprilaku baik, jujur, bertanggung jawab, menghormati hak orang lain, dan kerja keras jadi peserta didik akan dapat menentukan mana yang baik dan mana yang buruk dan memiliki tujuan hidup yang bermanfaat untuk dirinya, lingkungannya, dan agama yang dianutnya.

Bidang studi PKn di SMAN 9 Kota Malang merupakan mata pelajaran yang memuat tentang Pendidikan Karakter dan mengembangkan nilai-nilai Karakter 
yang ada dalam ideologi negara ini yaitu Pancasila. Bidang studi PKn sangat jelas mencantumkan Pendidikan Karakter dalam perangkat pembelajarannya sebagai pedoman guru Pendidikan Kewarganegaraan SMAN 9 Kota Malang dalam proses belajar mengajar. Nilai-nilai seperti saling menghormati antar sesama umat beragama, kemudian saling tolong-menolong, kejujuran, serta jiwa persatuan kesatuan dan sebagainya jelas tercantum dalam Rencana Pelaksanaan Pembelajaran. dimana guru bidang studi Pendidikan Kewarganegaran SMAN 9 Kota Malang harus mampu mengembangkan nilai-nilai Pendidikan Karakter tersebut dalam pembelajarannya agar lebih mudah dipahami oleh peserta didik.

Guru Pendidikan Kewarganegaraan di SMAN 9 Kota Malang tidak hanya sekedar mengajarkan materi-materi yang ada dalam Pendidikan Kewarganegaraan tetapi guru Pendidikan Kewarganegaraan juga berperan aktif dalam menumbuhkan pendidikan Karakter dalam diri peserta didik. Seperti pendapat dari Ratna Mega wangi (dalam Mulyasa 2012: 5) sebuah usaha untuk mendidik anak-anak agar dapat mengambil keputusan dengan bijak dan mempraktikkannya dalam kehidupan sehari-hari, sehingga mereka dapat memberikan kontribusi yang positif pada lingkungannya. Dari penjelasan tersebut bahwa PKn sebagai bidang studi yang memuat tentang Pendidikan Karakter harus diimbangi dengan kemampuan guru dalam mengembangkan nilai-nilai Pendidikan Karakter yang ada dalam bidang studi Pendidikan Kewarganegaraan dengan pedoman perangkat pembelajaran yang telah disesuaikan dengan kehidupan sosial yang ada.

Pernyataan diatas dapat diambil kesimpulan bahwa bidang studi PKn secara explisit mengenalkan dan mengembangkan nilai-nilai Pendidikan Karaker yang tujuannya menjadikan peserta didik di SMAN 9 Kota Malang untuk menginternalisasikan nilai- nilai karakter tersebut, Sesuai dengan pendapat dari (Gunawan 2012 : 39) bahwa Pendidikan karakter pada intinya bertujuan membentuk warga negara yang tangguh, kompetitif, berakhlak mulia, bermoral, bertoleran, bergotong royong, berjiwa patriotik, berkembang dinamis, berorientasi ilmu pengetahuan dan tekhnologi yang semuanya dijiwai oleh iman dan takwa kepada Tuhan Yang Maha Esa berdasarkan Pancasila.

Mengenai strategi implementasi Pendidikan Karakter dalam Pendidikan Kewarganegaraan. Dari keterangan diatas dapat ditarik kesimpulan bahwa strategi serta upaya guru Pendidikan Kewarganegaraan SMAN 9 Kota Malang dalam implementasi Pendidikan Karakter melalui bidang studi Pendidikan Kewarganegaraan di SMAN 9 Kota Malang dilakukan dengan pembiasaan serta penguatan. Artinya guru melakukan sesuatu secara berualang-ulang. Yang sengaja dilakukan agar dapat menjadi kebiasaan dalam diri siswa-siswi di SMAN 9 Kota Malang dan menguatkan kembali nilai-nilai Pendidikan Karakter yang ada artinya guru melakukan ajakan, dorongan, dan motivasi terhadap peserta didik.

Pendidikan Karakter yang diimplementasikan kedalam mata pelajaran Pendidikan Kewarganegaraan yang di dalamnya memuat berbagai macam nilainilai ediologi negara ini yaitu Pancasila. Dengan tujuan Pendidikan Karakter dalam bidang studi Pendidikan Kewarganegaraan di SMAN 9 Kota Malang mampu untuk membentuk peserta didik memiliki karakter yang baik serta mampu untuk menerapkan dalam kehidupannya sehari hari. Sesuai dengan Undang-Undang 20 Tahun 2003 tentang Sisdiknas sebagai landasan operasional dengan pesan yang terkait dengan Pendidikan Kewarganegaraan pada Pasal 3 ayat 2 tentang fungsi dan tujuan negara dikemukakan bahwa : "Pendidikan nasional berfungsi mengembangkan kemampuan dan membentuk watak serta 
peradaban bangsa yang bermartabat dalam rangka mencerdaskan kehidupan bangsa.

Bertujuan untuk berkembangnya potensi peserta didik agar menjadi manusia yang beriman dan bertakwa kepada Tuhan Yang Maha Esa, berakhlak mulia, sehat, berilmu, cakap, kreatif, mandiri dan menjadi warga negara yang demokratis serta bertanggungjawab. Evaluasiyang dilakukan oleh guru Pendidikan Kewarganegaraan di SMAN 9 dalam implementasi Pendidikan Kewarganegaraan yaitu kepada aspek kognitif, afektif serta psikomotor siswa. Tetapi dari ketiga aspek evaluasi yang dikemukakan oleh beliau diatas beliau menitik beratkan pada aspek sikap yaitu penilaian afektif untuk peserta didik di SMAN 9 Kota Malang. Menurut Dharmadi (2010:33) bahwa proses pertumbuhan belajar meliputi: (a) cognitive domain atau aspek pengetahuan, (b) affective domain atau aspek sikap, (c) psycho motoric atau aspek ketrampilan

Dari penilaian tersebut guru PKn di SMAN 9 Kota Malang dapat menjadikan sebagai tolak ukur keberhasilan Pendidikan Karakter dalam bidang studi PKn di SMAN 9 Kota Malang. SMAN 9 Kota Malang dalam mengimplementasikan Pendidikan Karakter telah berpedoman dengan Kurikulum yang telah disesuaikan oleh kebutuhan Pendidikan Karakter di Indonesia. Kemendiknas (2011) menyatakan dalam rangka lebih memperkuat pelaksanaan pendidikan karakter pada satuan pendidikan telah teridentifikasi 18 nilai yang bersumber dari agama, Pancasila, budaya dan tujuan pendidikan nasional yaitu: Religius, Jujur, Toleransi, Disiplin, Kerja keras, Kreatif, Mandiri, Demokratis, Rasa ingin tau, Semangat kebangsaan, Cinta tanah air, Menghargai prestasi, Bersahabat, Cinta damai, Gemar membaca, Peduli lingkungan, Peduli sosial dan Tanggung jawab.

Berkaitan dengan penjelasan di atas SMAN 9 Kota Malang juga berpedoman pada motto sekolah yang isinya yaitu mengejawantahkan ke dalam perwujudan pendidikan karakter yang cerdas dan dilandasi dengan sifat religius. Penjelasan diatas diperkuat dengan pendapat dari Gunawan (2012 : 32) bahwa berdasarkan kajian nilai-nilai agama, norma-norma sosial, peraturan, etika akademik, dan prinsip-prinsip HAM, telah teridentifikasi 80 butir nilai karakter yang dikelompokan menjadi berikut ini :

a) Nilai-nilai prilaku manusia dalam hubungannya dengan Tuhan Yang Maha Esa,

b) Nilai-nilai prilaku manusia dalam hubungannya dengan diri sendiri,

c) Nilai-nilai prilaku manusia dalam hubungannya dengan sesama manusia, dan,

d) Nilai-nilai prilaku manusia dalam hubungannya dengan kebangsaan Kegiatan ektrakulikuler yang ada di SMAN 9 Malang telah menyisipkan Pendidikan karakter dan mengembangkan nilai-nilai Pendidikan Karakter. Jadi apa yang didapatkan peserta didik dalam bidang PKn dapat dikembangkan juga dalam kegiatan ektrakulikuler sekolah seperti kegiatan ektrakulikuler paskibra di SMAN 9 Kota Malang yang didalamnya menyisipkan pendidikan karakter seperti disiplin, tanggung jawab, mandiri dan nasionalis, nilai-nilai tersebut sangat terkait dengan Pendidikan Kewarganegaraan.

Sesuai dengan fungsi dan tujuan pendidikan Nasional menurut UUSPN No. 20 Tahun 2003 Bab 2 Pasal 3“ Pendidikan nasional berfungsi mengembangkan kemampuan dan membentuk watak serta peradaban bangsa bertujuan untuk berkembangnya potensi peserta didik agar menjadi manusia yang beriman dan bertakwa kepada Tuhan Yang Maha Esa, berakhlak mulia, sehat, berilmu, cakap, kreatif, mandiri dan menjadi warga Negara yang demokrasi serta bertanggung jawab”.

Pendidikan Karakter itu juga telah diintegrasikan melalui kegiatan-kegiatan 
ektrakulikuler sekolah. Dalam kegiatan tersebut terdapat banyak sekali nilai-nilai karakter, yaitu nasionalisme, mandiri, tanggung jawab, dan kebersamaan. Ini merupakan nilai-nilai yang ada dalam bidang studi Pendidikan Kewarganegaraan Pernyataan diatas dapat diambil kesimpulan bahwa Pendidikan Kewarganegaraan berperan besar dalam membentuk karakter siswa-siswi SMAN 9 Kota Malang dalam membimbing mereka untuk lebih bertanggung Implementasi Pendidikan Karakter dalam bidang studi Pendidikan Kewarganegaraan sudah sesuai dengan apa yang diinginkan siswa-siswi di SMAN 9 Kota Malang. Guru bukan hanya mengajar tetapi juga memberikan contoh tauladan kepada siswa-siswinya agar selalu bersikap baik dalam kehidupan mereka sehari-hari.

Kesimpulan Hasil penelitian di SMAN 9 Kota Malang terkait dengan Pendidikan Karakter pada bidang studi PKn menurut mereka Pendidikan Karakter yang ada dalam mata pelajaran Pendidikan Kewarganegaraan sangatlah penting, mereka mengatakan bahwa nilai-nilai karakter yang ada pada mata pelajaran Pendidikan Kewarganegaraan di SMAN 9 Kota Malang mampu untuk membentuk karakter mereka menjadi lebih baik lagi. Merubah mereka dari yang berprilaku buruk menjadi baik dan yang baik menjadi lebih baik lagi semua ini juga tidak lepas dari peran guru Pendidikan Kewarganegaraan dalam pembelajaran di kelas dan juga diluar kelas.

Guru Pendidikan Kewarganegaraan di SMAN 9 Kota Malang mendidik siswa bukan hanya melalui materi di dalam kelas saja melainkan diluar kelas juga. Guru Pendidikan Kewarganegaraan juga memberikan contoh maupun pringatan dan sanksi yang tegas kepada seluruh siswa-siswi SMAN 9 Kota Malang yang berprilaku buruk. Yang diharapkan siswasiswi SMAN 9 Kota Malang merasa takut untuk melanggar peratuan sekolah sehingga Pendidikan Karakter dalam bidang studi Pendidikan Kewarganegaraan dapat terlaksana dengan baik. Ini dilakukan agar Pendidikan Karakter yang ada dalam bidang studi Pendidikan Kewarganegaraan dapat dengan mudah diterima dan dipahami oleh siswa-siswi SMAN 9 Kota Malang, membentuk prilaku mereka menjadi lebih baik dan bermanfaat untuk diri mereka sendiri dan orang lain.

Implementasi Pendidikan Karakter yang ada dalam mata pelajaran Pendidikan Kewarganegaraan sesuai dengan yang dikemukakan oleh Kemendiknas (2010 : 38) menyatakan Pendidikan karakter menjadi bagian yang tidak terpisahkan dari upaya pencapaian visi pembangunan nasional sebagaimana tertuang dalam Rencana Pembangunan Jangka Panjang Tahun 2005-2025, yaitu mengembangkan kemampuan dan membentuk watak serta peradaban bangsa yang bermartabat dalam rangka mencerdaskan kehidupan bangsa, bertujuan untuk berkembangnya potensi peserta didik agar menjadi manusia yang beriman dan bertakwa kepada Tuhan Yang Maha Esa, berakhlak mulia, sehat, berilmu, cakap, kreatif, mandiri dan menjadi warga negara yang demokratis serta bertanggung jawab.

\section{Kendala-kendala yang dihadapi dalam Implementasi Pendidikan Karakter melalui Bidang Studi Pendidikan Kewarganegaraan}

Berdasarkan hasil penelitian yang sudah dianalisis oleh peneliti tentang Implementasi Pendidikan Karakter Melalui Bidang Studi Pendidikan Kewarganegaraan di SMAN 9 Kota Malang. Adapun dalam penelitian ini, penulis menggali informasi kepada para informan mengenai apa saja Kendala Implementasi Pendidikan Karakter melalui bidang studi Pendidikan Kewarganegaraan di SMAN 9 Kota Malang. 
Pendidikan Kewarganegaraan di SMAN 9 Kota Malang salah satunya yaitu dari siswa-siswinya sendiri. Karena setiap karakter anak satu dengan yang lainnya juga berbeda ada yang baik dan bisa diatur, ada juga yang tidak baik dan susah untuk diberi bimbingan. Walaupun guru Pendidikan Kewarganegaraan telah menggunakan berbagai metode dalam pembelajaran dan juga memberikan tauladan kepada seluruh siswa-siswi SMAN 9 Kota Malang agar mampunyai karakter yang baik tapi pada beberapa kasus masih saja ada anak yang melakukan kenakalan disekolah yang disebabkan oleh faktor dari lingkunganya tempat anak tersebut bermain. Ini merupakan tantangan bagi seluruh guru di SMAN 9 Kota Malang.

Pendidikan Kewaganegaraan yang semestinya memberikan contoh dan tauladan terkadang juga lupa dari tanggung jawabnya sebagai seorang guru yang dijadikan panutan oleh siswa-siswinya. Guru Pendidikan Kewarganegaraan masih sering terlambat datang ke sekolah.

Beberapa kendala dalam Pendidikan Karakter melalui bidang studi Pendidikan Kewarganegaraan, guru maupun murid masih banyak yang terlambat datang ke sekolah. Terutama untuk siswanya masih ada banyak siswa-siswi yang membuang sampah sembarangan dilingkungan sekolah padahal sekolah memiliki sanksi-sanksi yang tegas bagi siapa saja yang melanggar peraturan.

Kesimpulannya bahwa tantangan dari Pendidikan Kewarganegaraan sebagai mata pelajaran yang memiliki peran besar dalam menumbuhkan pendidikan karakter di Indonesia, kendalanya yaitu dari perkembangan zaman yang semakin berkembang atau dampak globalisasi. Budaya negara ini semakin hilang karena anak-anak lebih memilih budaya asing yang menurut mereka baik tapi pada kenyataannya budaya tersebut semakin menjerumuskan anak-anak kepada budaya yang negatif, Nilai-nilai Pendidikan Karakter yang siswa dapat di sekolah belum tentu mereka dapatkan diluar sekolah sehingga pengaruh budaya negativ dapat dengan mudah mempengaruhi anakanak, karena waktu anak paling banyak ada di luar sekolah. Tantangan yang menjadi problem yang sangat serius bagi bidang studi Pendididikan Kewarganegaraan dan juga guru Pendidikan Kewarganegaraan di SMAN 9 Kota Malang

\section{Solusi dalam mengatasi kendala-kendala Implementasi Pendidikan Karakter melalui bidang studi Pendidikan Kewarganegaraan}

Dari semua kendala-kendala yang ada, peneliti juga ingin mengetahui solusi apa yang seharusnya dilakukan dalam mengatasi kendala-kendala tersebut dalam implementasi Pendidikan Karakter melalui bidang Studi Pendidikan Kewarganegaraan agar dapat berjalan dengan lancar dan efektif. Semua itu tidak akan terwujud dengan waktu yang sangat singkat karena diperlukan usaha dan kerja keras dewan guru bersama kepala sekolah serta seluruh komponen yang ada di SMAN 9 Kota Malang untuk mewujudkannya. Butuh proses karena membentuk karakter anak yang baik itu tidak semudah membalikan telapak tangan.

Untuk mengetahui solusi apa yang dapat diupayakan di SMAN 9 Kota Malang dalam mengatasi kendala-kendala dalam implementasi Pendidikan Karakter melalui bidang studi Pendidikan Kewarganegaraa peneliti melakukan wawancara dengan bapak HH selaku kepala sekolah yang juga Berdasarkan informasi yang diperoleh dari informan diatas maka dapat disimpulkan bahwa solusi dalam mengatasi kendalaimplementasi Pendidikan Karakter melalui bidang studi Pendidikan Kewargangaraan. Yaitu komunikasi yang baik seluruh komponen yang ada di SMAN 9 Kota Malang, ketauladanan dari seorang guru, 
adanya kesadaran dalam diri siswa maupun guru-guru yang ada di SMAN 9 Kota Malang dalam bersikap yang baik, peran orang tua dalam memberikan Pendididkan Karakter dan melakukan pengawasan terhadap anaknya.

\section{SIMPULAN}

Berdasarkan hasil penelitian dan pembahasan yang dilakukan oleh peneliti tentang "Implementasi Pendidikan Karakter Melalui Bidang Studi Pendidikan Kewarganegaan di SMAN 9 Kota Malang” maka di akhir bab ini peneliti dapat menyimpulkan pokok-pokok pembahasan sebagai berikut: Implementasi Pendidikan Karakter melalui bidang studi Pendidikan Kewarganegaraan di SMAN 9 Kota Malang merupakan mata pelajaran yang memuat tentang Pendidikan Karakter dan mengembangkan nilai-nilai Karakter yang ada dalam ideologi negara ini yaitu Pancasila. Strategi guru PKn SMAN 9 Kota Malang dalam implementasi Pendidikan Karakter melalui bidang studi Pendidikan Kewarganegaraan dilakukan dengan ketauladanan, pembiasaan atau penguatan. Artinya guru melakukan sesuatu secara berulang-ulang. Yang sengaja dilakukan agar dapat menjadi kebiasaan dalam diri siswa dan menguatkan kembali nilai-nilai Pendidikan Karakter yang ada.

Evaluasi yang dilakukan oleh guru Pendidikan Kewarganegaraan di SMAN 9 dalam implementasi Pendidikan Kewarganegaraan yaitu kepada aspek kognitif, afektif serta psikomotor siswa. Jadi apa yang didapatkan peserta didik dalam bidang PKn dapat dikembangkan juga dalam kegiatan ektrakulikuler sekolah seperti kegiatan ektrakulikuler paskibra di SMAN 9 Kota Malang yang didalamnya menyisipkan pendidikan karakter seperti disiplin, tanggung jawab, mandiri dan nasionalis, nilai-nilai tersebut sangat terkait dengan Pendidikan Kewarganegaraan. Guru Pendidikan Kewarganegaraan di
SMAN 9 Kota Malang mendidik siswa bukan hanya melalui materi di dalam kelas saja melainkan diluar kelas juga.

Kendala-kendala yang dihadapi dalam implementasi Pendidikan Karakter melalui bidang studi PKn yaitu Kendala yang dihadapi dalam implementasi Pendidikan Karakter melalui bidang studi Pendidikan Kewarganegaraan di SMAN 9 Kota Malang salah satunya yaitu dari siswa-siswinya sendiri. Beberapa kasus masih saja ada anak yang melakukan kenakalan disekolah yang disebabkan faktor dari lingkunganya tempat anak tersebut bermain. Ini merupakan tantangan bagi seluruh guru di SMAN 9 Kota Malang. Kendala dalam Pendidikan Karakter melalui bidang studi Pendidikan Kewarganegaraan, guru maupun murid masih banyak yang terlambat datang ke sekolah. Terutama untuk siswanya masih ada banyak siswa-siswi yang membuang sampah sembarangan dilingkungan sekolah padahal sekolah memiliki sanksi-sanksi yang tegas bagi siapa saja yang melanggar peraturan.

Kendalanya yaitu dari perkembangan zaman atau dampak globalisasi. Budaya negara ini semakin hilang karena anakanak sekarang ini lebih memilih budayabudaya asing yang menurut mereka baik tapi pada kenyataannya budaya tersebut semakin menjerumuskan anak-anak kepada budaya yang negativ. Nilai-nilai Pendidikan Karakter yang siswa dapat di sekolah belum tentu mereka dapatkan diluar sekolah sehingga pengaruh budaya negativ dapat dengan mudah mempengaruhi anakanak, karena waktu anak paling banyak ada di luar sekolah

Solusi yang ditawarkan dalam Implementasi Pendidikan Karakter melalui bidang studi Pendidikan Kewarganegaraan yaitu komunikasi yang baik seluruh komponen yang ada di SMAN 9 Kota Malang, ketauladanan dari seorang guru, adanya kesadaran dalam diri siswa maupun 
guru-guru yang ada di SMAN 9 Kota Malang dalam bersikap yang baik, peran orang tua dalam memberikan Pendididkan Karakter dan melakukan pengawasan terhadap anaknya agar Pendidkan Karakter yang di dapat siswa-siswi SMAN 9 Kota Malang melalui bidang studi Pendidikan Kewarganegaraan tidak mudah hilang ketika siswa-siswi tersebut berada di luar sekolah.

\section{DAFTAR PUSTAKA}

Badan Standar Nasional Pendidikan (BSNP). 2006. Panduan Penyusunan Kurikulum Tingkat Satuan Pendidikan Jenjang Pendidikan Dasar Dan Menengah. Jakarta. BSNP.

Dharmadi, Hamid. 2010. Pengantar Pendidikan Kewarganegaraan. Bandung. Alfabeta Gunawan, Heri. 2012. Pendidikan Karakter Konsep Dan Implementasi. Bandung. Alfabeta
Mulyasa. E. 2012. Manajemen pendidikan karakter. Jakarta. PT. Bhumi Aksara.

Moleong. J. Lexy 2011. Metode Penelitian Kualitatif Edisi Revisi. Bandung: PT Remaja Rosdakarya

Samani, Muchlas dan Hariyanto. 2012. Konsep dan model pendidikan karakter. Bandung. PT. Remaja Rosdakarya

Samsuri. 2011. Pendidikan Kewarganegaraan Sebagai Wahana Membangun Karakter Bangsa. Yogyakarta. UNY Press

Undang-Undang Republik Indonesia Nomor 20 Tahun 2003 tentang Sistem Pendidikan Nasional UUSPN Zuriah, Nurul. 2011. Pendidikan Moral Dan Budi Pakerti Dalam Prespektif Perubahan. Jakarta. PT. Bhumi Aksara

Zuriah, Nurul. 2009. Metodologi Penelitian Sosial Dan Pendidikan. Jakarta. PT. Bhumi Aksara. 